\title{
Energy analysis of charging infrastructure for electric vehicles on the TEN-T road network
}

\author{
Maciej Gis ${ }^{1, *}$, Mateusz Bednarski ${ }^{2}$, and Piotr Orliński ${ }^{2}$ \\ ${ }^{1}$ Motor Transport Institute, ul. Jagiellonska 80, 03-301 Warsaw, Poland \\ ${ }^{2}$ Warsaw University of Technology, Faculty of Automotive and Construction Machinery Engineering, \\ ul. Narbutta 84, 02-524 Warsaw, Poland
}

\begin{abstract}
Electromobility is a European vision of future motorization. In Poland, there are plans to introduce a million vehicles of this type by 2030 . Currently, their share is marginal (about 1 percent). This vision is to be made real. This is due to the fact that vehicle manufacturers are developing newer $\mathrm{EV}$ vehicle constructions. Increasing the number of electric vehicles requires the development of their charging infrastructure. Based on the work of the authors regarding the EV vehicle charging network on the Trans-European Transport Network road network, it was possible to extend this issue with energy calculations related to energy demand for supplying the EV vehicle charging network. This is an important topic from the point of view of the State's energy needs. The calculations made in the article present the problem of the need to increase the production of electricity, which in the case of Poland is associated with increased emissions of harmful substances and the possibility of periodic interruptions in the supply of electricity. Due to excessive domestic consumption with too little production. The second issue is the need to supply electricity to the charging station (infrastructure), as well as transmission losses, which limit the possibility of building multistation fast charging stations. The issue presented by the authors in this article is one of the key problems relating to the introduction of electromobility in Poland. The key is to determine how large the demand for electricity in the country will be if a greater number of electric vehicles is put into operation. Considering that there are power shortages during a hot summer, this may affect the possibility of using electric vehicles in the country.
\end{abstract}

\section{Introduction}

The first attempts to work on electric vehicles began around 1800. Their popularity was significant until 1900. In later years they were supplanted by vehicles fueled with conventional fuels [10].

\footnotetext{
* Corresponding author: maciej.gis@its.waw.pl
} 
Electric vehicles have been considered as vehicles for everyday use for about 5-6 years. This is the result of an increasing number of vehicles in the world, and thus a significant increase in emission of harmful exhaust gas, which in the end has negative impact on the natural environment and human health. These aspects combined with shrinking resources of oil-derived fuels have contributed to the intensification of works on alternative drives and fuels in transport [11-13, 17, 18].

According to the IEA report, the number of electric vehicles (BEV), hydrogen vehicles (FCEV) and plug-in hybrid (PHEV) on global roads in 2017 reached 3.1 million copies (an increase of $54 \% \mathrm{y} / \mathrm{y})$. In 2017, more than 1 million electric cars were sold in total (54\% more than in 2016), half of which (580 thousand) in China. The second place was taken by the United States with a result of 280.000 vehicles [14].

On the roads of the Middle Kingdom, there are currently 1.23 million electric vehicles ( $40 \%$ of the global EV fleet), in Europe 0.82 million, in the US 0.76 million, while in the rest of the world -0.3 million. In 2018, the largest EV share in the new vehicle market was recorded in Norway (39.2\%), Iceland (11.7\%) and Sweden (6.3\%). China (2.2\%), Germany (1.6\%), USA (1.2\%) and Japan (1.0\%) ranked next [14].

It is assumed that electric vehicles will be one of the most important pillars of the automotive industry. The development of this type of vehicle now allows the assumption that in the medium-term, i.e. until 2030, they are to account for around $30-35 \%$ of all vehicle sales in the world. For this plan to be accomplished their market share must be increased. In addition to convincing customers to purchase vehicles, it is also necessary to provide the right infrastructure. In the case of these vehicles, a network of vehicle charging points must be built to ensure that the vehicles' batteries are charged to $80 \%$ within 30 minutes or faster [9]. In Poland, there are currently over 300 generally available charging stations for electric cars - according to the estimates of the Polish Alternative Fuels Association (there are about 100.000 in Europe). The largest operator in Poland is Greenway. At the end of 2017, the company had 33 own charging stations (32 fast and one accelerated AC) and 4 partner stations. Now, 78 own and 15 partner stations operate in the Greenway network, which in total gives $83[15,19,20,21]$.

\section{Electric vehicles range}

Several models of electric cars are available on the market. Currently in Poland, despite an extensive promotion of electric vehicles, their sale is still insignificant. It represents less than $1 \%$ of the sales of all vehicles on the market. The number of purchased copies in the years 2015-2018 is presented in Table 1.

The vehicles offered so far have a fairly diverse range. It is largely dependent on the capacity of the batteries used. Based on the range of available electric vehicles, it is possible to determine the average mileage that vehicles can pass in a mixed cycle with fully charged batteries (table 2) [2-5]. It should be noted that the values given are those declared by the producers. In real traffic conditions, they can be much smaller.

When calculating the average range of electric vehicles available in Poland, vehicles such as Tesla Model S, Hyundai Kona Electric (extended range) and Nissan LEAF with $62 \mathrm{kWh}$ battery are not included. These vehicles were rejected due to the much wider range, which would affect the overall average range of these vehicles included in the analysis. If the above vehicles had not been rejected, the average range for other available electric vehicles would increase significantly.

Based on the collected data, it has been determined that the average mileage of electric vehicles available in Poland is about $175 \mathrm{~km}$. On this basis, further calculations presented in this work were performed. 
Table 1. Number of electric vehicle registrations in the country in the years 2015-2018 [1].

\begin{tabular}{|c|c|c|c|c|c|}
\hline Model & $\mathbf{2 0 1 5}$ & $\mathbf{2 0 1 6}$ & $\mathbf{2 0 1 7}$ & $\mathbf{2 0 1 8}$ & Summary \\
\hline BMW i3 & 67 & 32 & 117 & 164 & 380 \\
\hline Nissan e-NV200 & 9 & 3 & 21 & 10 & 43 \\
\hline Nissan LEAF & 24 & 8 & 239 & 269 & 540 \\
\hline Tesla Model S & 21 & 4 & 40 & 20 & 85 \\
\hline Tesla Model X & - & - & 31 & 33 & 64 \\
\hline Volkswagen Golf & 1 & 3 & 13 & 41 & 58 \\
\hline Volkswagen up! & 1 & 3 & 2 & 1 & 7 \\
\hline Renault ZOE & - & - & 11 & 49 & 60 \\
\hline Other & - & - & 10 & 50 & 60 \\
\hline Summary on the market & $\mathbf{1 2 3}$ & $\mathbf{5 3}$ & $\mathbf{4 8 4}$ & $\mathbf{6 3 7}$ & $\mathbf{1 2 9 7}$ \\
\hline
\end{tabular}

\section{TEN-T transport routes}

The Trans-European Transport Network (TEN-T) is an instrument for coordinating and ensuring coherence and complementarity of infrastructure investments [6].

As a result of the revision of the TEN-T guidelines completed in 2013, a new agreement has been established in the territory of the EU Member States. This system includes a core network that underpins the development of the transport network on which EU activities are to focus, in particular on cross-border sections, missing links, multimodal connections and major bottlenecks, and a comprehensive network ensuring the availability and connectivity of all EU regions [6].

The trans-European TEN-T transport network includes [6]:

- road, rail, air, sea and river routes constituting the most important connections from the point of view of the development of the European Union,

- point elements of infrastructure in the form of sea, air, inland and road-rail terminals.

Its integral component is also intelligent transport systems, the implementation of which contributes to the improvement of network capacity, traffic safety and reduction of environmental pollution by transport [6].

The aim of developing the TEN-T network is to ensure territorial cohesion of the EU and to improve free movement of people and goods. An efficiently functioning transport system within the European Union is to contribute to the improvement of the operation of the single internal market, to stimulate the region's economic growth and to increase the competitiveness of individual Member States and the entire EU on a global scale [6].

The objective of EU policy in the context of the development of the TEN-T network is to create a coherent and interoperable, multimodal transport network with uniform, high technical parameters throughout the European Union [6]. 
Because of the nature of the work, the article focuses only on road transport. According to [7] for the TEN-T base network in Poland in 2010, roads in the Baltic-Adriatic corridor, the average traffic volume was 13,284 vehicles /day, while roads located in the North Sea-Baltic corridor 10,876 vehicle per day. On national international roads, by far the largest traffic load, amounting to over 35 thousand vehicles/day (including almost 24,000 passenger cars daily), was noted in the Śląskie Voivodship, followed by 26,513 vehicles/day (including 17,764 passenger cars/day) in the Opolskie Voivodeship. High traffic load, amounting to more than 20,000 vehicles/day (including over 13,000 passenger cars/day), was also recorded in the following provinces: Małopolskie and Mazowieckie [7].

On the remaining national roads, by far the largest traffic, with over 11,000 vehicles/day (including 8,214 passenger cars/day), was noted in the Śląskie Province. Very high load on the network of other national roads, amounting to more than 9,000 vehicles/day (including over 6,000 passenger cars/day), also occurred in the following provinces: Małopolskie and Wielkopolskie [7].

The traffic forecast for 2020 was developed for the state of the national road network in 2015. The assumption was made that no changes will take place therein and there will be no significant factors that may affect the changes in traffic behavior [7,8].

According to [8], the highest road load according to the adopted forecast will take place around the largest urban agglomerations in Poland (including Warsaw, Katowice and Kraków, Poznań, Wrocław, Trójmiasto), where the average daily traffic volume is expected to exceed 20 thousand vehicles [7].

\section{Proposal to depoy charging stations for electric vehicles at the TEN-T transport routes}

On the basis of TEN-T transport routes and traffic forecasts on national roads in 2020, developed by GDDKiA, it was possible to determine road sections of the largest and most significant importance. These roads include, among others national road no. 7 (TricityWarsaw-Krakow), A1 motorway (Tricity-Lódź), A2 motorway (Warsaw-Frankfurt/Oder), A4 motorway (Świecko-Kraków), express road S8 - A1 motorway - national road 1 (Warsaw-Katowice) or national road 17 (Warsaw-Hrebenne).

Based on the above it is proposed to deploy fast charging stations for electric vehicles. The distance between the charging points was calculated based on the average range of electric vehicles and the possibility of charging electric vehicles. The exact calculation of the distance between the charging stations is shown in Table 2 .

Table 2. Calculating the distance between electric vehicle charging stations.

\begin{tabular}{|c|c|}
\hline & Range \\
\hline The average range of electric vehicles when the batteries are $100 \%$ charged & $175 \mathrm{~km}$ \\
\hline The average range of electric vehicles when the batteries are $80 \%$ charged & $140 \mathrm{~km}$ \\
\hline Current reserve in $15 \%$ batteries & $26 \mathrm{~km}$ \\
\hline $5 \%$ safety factor & $\sim 9 \mathrm{~km}$ \\
\hline Distance between electric vehicle charging stations & $\sim \mathbf{1 1 0} \mathbf{~ k m}$ \\
\hline
\end{tabular}

Based on the calculated distance between the charging points, it was possible to determine the minimum number of charging stations for electric vehicles on routes within TEN-T.

The suggested proposal comprises the construction of a quick charging station on the forecasted main transport routes in the country. Considering the assumptions regarding the 
distance between fast loading points and analyzing the possibility of their location and considering the current road infrastructure in the country (intersections, interchanges, road type), it was possible to determine the minimum number of charging points on individual routes (Świecko-Suwałki -14; Trójmiasto-Kraków - 12; Trójmiasto-Łódź - 6; ŁódźWrocław - 6; Katowice-Rzeszów - 4; Warszawa-Hrebenne - 6; Warszawa-Katowice - 6; Warszawa-Katowice - 6; Warszawa-Kraków - 6; Overall-60).

Taking into account such variables as the location and infrastructure of given road sections, it was possible to determine the number of fast charging points for electric vehicles. Their minimum number is 60 points. With such infrastructure it will be possible to use electric vehicles on roads within the TEN-T transport routes and constituting road sections that will be heavily loaded in the perspective of 2020 , without worrying about the lack of space for charging vehicles.

\section{Energy demand of an electric vehicle}

The demand for electricity is growing in Poland. According to the available information, in 2017 more than $170 \mathrm{TWh}$ of energy was produced in the country. It is $2.2 \%$ more than in 2016. Table 3 presents the division of electricity production from various sources for years 2016-2017.

Table 3. Electricity production in Poland [16].

\begin{tabular}{|c|c|c|c|c|}
\hline \multirow{2}{*}{ Specification } & $\mathbf{2 0 1 6}$ & $\mathbf{2 0 1 7}$ & Change \\
\cline { 2 - 5 } & \multicolumn{2}{|c|}{ GWh } & $\%$ \\
\hline Total production & $\mathbf{1 6 6 5 9 7}$ & $\mathbf{1 7 0 3 3 5}$ & $+\mathbf{2 . 2}$ \\
\hline Thermal power stations & 140378 & 140259 & -0.1 \\
\hline - brown coal & 51082 & 52281 & +2.3 \\
\hline - coal & 80173 & 79265 & -1.1 \\
\hline - gas & 5604 & 6161 & +9.9 \\
\hline - biomass/biogas & 3519 & 2552 & -17.5 \\
\hline Hydroelectric power stations & 2335 & 2719 & +16.4 \\
\hline - including pumped storage & 482 & 474 & $-1,6$ \\
\hline Wind power stations & 2981 & 3485 & +16.9 \\
\hline Industrial power plants & 9897 & 11417 & +15.4 \\
\hline Independent power plants - renewable energy installations & 11006 & 12454 & +13.2 \\
\hline
\end{tabular}

On the basis of own tests of an electric vehicle in real traffic conditions, it was possible to determine its average energy consumption. Then it was determined with the assumption of daily runs (about $60 \mathrm{~km}$ ), what would be the energy demand of one vehicle and energy costs related to it (Table 4). 
Table 4. Annual energy consumption needed to recharge the batteries of one vehicle.

\begin{tabular}{|c|c|}
\hline Specification & \\
\hline Daily mileage on business days & $60 \mathrm{~km}$ \\
\hline Daily mileage on Sundays and holidays & $60 \mathrm{~km}$ \\
\hline Annual mileage on business days & $15060 \mathrm{~km}$ \\
\hline Aaily mileage on Sundays and holidays & $6840 \mathrm{~km}$ \\
\hline Total mileage & $\mathbf{2 1 ~ 9 0 0 ~} \mathbf{~ m}$ \\
\hline Price 1 kWh for a household (G11 tariff) & $0,55 \mathbf{z l} / \mathbf{k W h}$ \\
\hline The cost of charging one vehicle a year & $\mathbf{2 5 2 9 . 4 5} \mathbf{~ z l}$ \\
\hline Annual energy consumption needed to recharge the batteries of one vehicle & $\mathbf{4 5 9 9} \mathbf{~ k W h}$ \\
\hline
\end{tabular}

Next, the results of the annual electricity consumption needed to charge the batteries of one electric vehicle were referred to the assumed introduction in Poland of a million electric cars. On this basis, the annual energy consumption needed to recharge the batteries of one million electric vehicles could be determined (Table 5). Next, the percentage of energy demand in the country will be estimated.

Table 5. Energy demand for powering electric vehicles.

\begin{tabular}{|c|c|}
\hline Specification & \\
\hline $\begin{array}{c}\text { Annual energy consumption needed to recharge the batteries of one electric } \\
\text { vehicle }\end{array}$ & $4599 \mathrm{kWh}$ \\
\hline $\begin{array}{c}\text { Annual energy consumption needed to recharge the batteries of a million electric } \\
\text { vehicles }\end{array}$ & $4,599 \mathrm{TWh}$ \\
\hline A change in energy demand while supplying a million electric vehicles & $+2.7 \%$ \\
\hline
\end{tabular}

Calculations show that with one million vehicles the energy demand of the country will increase by $2.7 \%$. This is not a significant change with regard to the energy demand in the country in 2017 , which amounted to over $170 \mathrm{TWh}$. One can say that the only problem is the time of charging electric vehicles. It is best for financial reasons that this process takes place at night. The tariff adopted for the purpose of the calculation is a tariff applicable to households (G11) and amounts to $0.55 \mathrm{PLN} / \mathrm{kWh}$. With this assumption, the annual costs relating to the charging of an electric vehicle amount to PLN 2529.45. With regard to conventional vehicles, this is a significant difference at the moment.

\section{Infrastructure for charging electric vehicles on the TEN-T road network}

On TEN-T routes, the so-called quick chargers for electric vehicles are logical. There are currently $55 \mathrm{kWh}$ variants. On this basis, it is possible to calculate the energy demand assuming that all specified stations are simultaneously used (the so-called black scenario). The above calculations showed that a sufficient number of stations on the TEN-T road network is 60 points. Considering the number of electric vehicles registered in the country (table 1), at each point there should be four stations for simultaneous charging of electric vehicles. This gives an overall ability to load 240 vehicles simultaneously in the country (table 6). 
Table 6. The number of charging points for electric vehicles.

\begin{tabular}{|c|c|}
\hline Specification & \\
\hline The number of charging points for electric vehicles on TEN-T transport routes & 60 \\
\hline Number of stands at each charging point & 4 \\
\hline The total number of electric vehicles that can be recharged & $\mathbf{2 4 0}$ \\
\hline
\end{tabular}

With such a large number of stations and the assumption that electric vehicles on routes will be loaded within 30 minutes (battery charging up to 80\%), the energy demand to power fast chargers can be determined. Once these values were determined, it was possible to determine daily and annual energy demand (Table 7).

Table 7. Energy demand for supplying fast chargers $(55 \mathrm{kWh})$ for powering the batteries of electric vehicles.

\begin{tabular}{|c|c|}
\hline Specification & Change \\
\hline Hourly energy demand of fast chargers & $55 \mathrm{~kW} / \mathrm{h}$ \\
\hline Energy demand of fast chargers for charging electric vehicle batteries in $80 \%$ & $27.5 \mathrm{~kW} / \mathrm{h}$ \\
\hline Individual energy demand & $\mathbf{6 . 6} \mathbf{M W h}$ \\
\hline Daily energy demand & $\mathbf{0 . 3 1 6 8} \mathbf{~ G W h}$ \\
\hline Annual energy demand & $\mathbf{1 1 5 . 6 3 2} \mathbf{G W h}$ \\
\hline
\end{tabular}

\section{Conclusions}

The proposal to build fast-charging points for electric vehicles on roads belonging to the TEN-T transport routes and constituting road sections that will be heavily loaded in the perspective of 2020 , allowed to determine that to move the above-mentioned it is necessary to build 60 charging points for the type of vehicle. Other conclusions are:

- the proposal to build fast-loading points for vehicles would already allow the operation of available electric vehicles on the main transport routes,

- taking into account the proposal to build charging points on the main transport routes and the assumed development of electric vehicles (increasing their range) will enable further development of the network of charging points beyond the main transport routes,

- the development of the network of charging points can have a significant impact on the popularization of electric vehicles, and thus reduce the emission of harmful substances from transport,

- the increase in the energy load associated with the increase in the number of electric cars amounting to $2.7 \%$ will have insignificant environmental importance, considering lower consumption of petrol due to the limitation of the use of cars with an internal combustion engine.

\section{References}

1. www.samar.pl

2. www.bmw.pl

3. www.nissan.pl

4. www.tesla.com 
5. www.volkswagen.pl

6. www.mib.gov.pl

7. Praca zbiorowa: „Przesłanki narodowego planu wodoryzacji transportu samochodowego w Polsce”. Projekt HIT-2-Corridors. Sprawozdanie z realizacji pracy nr 5502/ITS. 25.09.2015

8. www.gddkia.gov.pl

9. K. Qian, Ch. Zhou, M. Allan, Y. Yuan, Modeling of Load Demand Due to EV Battery Charging in Distribution Systems (IEEE Power \& Energy Society, 2010)

10. K. Rajashekara, Present Status and Future Trends in Electric Vehicle Propulsion Technologies (IEEE Power \& Energy Society, 2013)

11. Biała Księga. Plan utworzenia jednolitego obszaru transportu - dążenie do osiągnięcia konkurencyjnego i zasobooszczędnego systemu transportu. KOM (2011)

12. J. Merkisz, I. Pielecha, Alternatywne paliwa i układy napędowe pojazdów (WPP, Poznań, 2004)

13. S. W. Kruczyński, M. Ślęzak, W. Gis, P. Orliński, Eksploatacja i Niezawodność, 18, 3, 342-347 (2016)

14. http://www.elektro.info.pl/aktualnosc/id8599, iea-liczba-pojazdow-elektrycznych-naswiecie-przekroczyla-3-mln-sztuk

15. https://wysokienapiecie.pl/13819-stacje-ladowania-powstaja-przy-trasach-i-wmiastach/

16. https://rynek-energii-elektrycznej.cire.pl/st,33,207,tr,75,0,0,0,0,0,podstawowedane.html

17. J. Merkisz, J. Pielecha, P. Lijewski, Exhaust emissions from vehicles in real traffic conditions in the Poznan agglomeration (21 ${ }^{\text {st }}$ International Conference on Modelling, Monitoring and Management of Air Pollution, Siena, Italy, 2013)

18. W. Gis, J. Pielecha, J. Waśkiewicz, Use of certain alternative fuels in road transport in Poland (Scientific Conference on Automotive Vehicles and Combustion Engines KONMOT, Krakow, Poland, 2016)

19. R. Jasinski, Mass and number analysis of particles emitted during aircraft landing, E3S 44, 00057

20. R. Jasinski, J. Pielecha, J. Markowski, Emission of particulate matter during aircraft landing operation, E3S, 10 (2016)

21. Z. Chłopek, J. Lasocki, P. Wójcik A. J. Badyda, International Journal of Green Energy, 15, 13, 773-779 